\title{
THE ACHIEVEMENT OF GENRE PARAGRAPH WRITING ABILITY OF HIGH SCHOOL STUDENTS ASSESSED THROUGH INTENSIVE AND RESPONSIVE WRITING ASSESSMENT
}

\author{
I Komang Budiarta \\ English Education Study Program, Faculty of Teacher Training and Education \\ Mahasaraswati Denpasar University \\ Email:mrbudi@unmas.ac.id
}

\begin{abstract}
Writing is one of language skills that is the most difficult skill to be mastered. This skill should be taken into account in teaching learning process. The English teachers at high schools in Badung, Gianyar and Denpasar gave writing test to their students by using a test that provided some topics which made the students difficult to imagine, develop their ideas and sometimes the test was not appropriate for their students' writing level. The present research was intended to figure out the achievement and the quality of the genre paragraph which was assessed by administering intensive and responsive writing assessment. The present research used an ex-post facto research design. The samples of the present study were taken from 16 schools in the aforementioned three regencies. The obtained data were then analyzed by means of norm-reference measure of five standard values. The result showed that $71 \%$ of the samples were successful; meanwhile, 29\% of the samples were unsuccessful in writing genre paragraph which was assessed by administering intensive and responsive writing assessment. In addition, the quality of their genre paragraphs was mainly good, but the needed extra effort on narrative.
\end{abstract}

Keywords: achievement, genre paragraph writing ability, and intensive and responsive writing assessment.

\begin{abstract}
ABSTRAK
Menulis merupakan salah satu keterampilan berbahasa yang paling sulit dikuasai. Keterampilan ini harus diperhitungkan dalam proses belajar mengajar. Guru bahasa Inggris di SMA di Badung, Gianyar dan Denpasar memberikan tes menulis kepada siswanya dengan menggunakan tes-tes yang memberikan beberapa topik yang terkadang membuat siswa sulit dalam membayangkan dan mengembangkan ide-idenya. Di samping itu, tes-tes yang digunakan juga tidak sesuai dengan tingkat kemampuan menulis siswanya. Penelitian ini bertujuan untuk mengetahui pencapaian dan kualitas genre paragraf yang dinilai melalui penilaian menulis yang dikategorikan pada level intensif dan responsif. Penelitian ini menggunakan desain penelitian ex-post facto. Sampel penelitian ini diambil dari 16 sekolah di tiga kabupaten tersebut. Data yang diperoleh kemudian dianalisis dengan menggunakan ukuran acuan norma lima nilai standar lalu hasilnya dideskripsikan. Hasil penelitian menunjukkan $71 \%$ sampel berhasil sedangkan 29\% sampel tidak berhasil menulis paragraf bergenre yang dinilai dengan penilaian menulis pada level intensif dan responsif. Selain itu, kualitas genre paragraf sudah memenuhi kriteria penilaian yang digunakan yaitu format, tanda baca, isi, organisasi dan tata bahasa walaupun masih perlu ditingkatkan pada isi.
\end{abstract}

Kata kunci: capaian, kemampuan menulis genre paragraf, dan penilaian menulis intensif dan responsif. 


\section{INTRODUCTION}

Writing skill as one of the most important language skills enables students to express their ideas in a 'controllable' way. Writing provides the teachers so many aspects that should be taken into account. In addition, they should consider those aspects both in teaching and assessing the students' writing ability. Both teaching and assessing writing are challenging for teachers. Brown (2004) furthermore mentions that writing skill, which is categorized as productive skill, should be taught and assessed in different ways with receptive skills. As writing is an active skill, the teachers should actively involve the students in the classroom activity. This learning atmosphere facilitates the students to produce the language that they have already studied in the classroom. Writing is a productive skill which takes a long and complicated process; consequently, it is of necessary for the teachers to provide plenty rooms of practices so that they can improve their writing skill.

In the teaching and learning process especially in writing, the teachers need to assess their students and should know how far their students' ability and their understanding in writing. In assessing practice, usually the teacher assesses the students in objective without using any scoring procedure. Thus, it showed the subjective result. The teachers only explain the material and then give them a topic. In addition, the teachers ask to the student to make a paragraph according to the topic which has been given. This made the teachers did not know their students' improvement especially their ability in writing and producing their ideas in the form of unified and coherent writing product.
In teaching and learning process of writing, the teachers are not only giving attention to teach the material but also to evaluate the students' ability or the way should assess the students. Teachers should know that teaching and assessing cannot be separated in learning process. Assessing is a process to collect information about the students' ability in writing skill. The aim of assessing is to know how far the students' ability in writing skill and to know the strength and the weaknesses of the students. Moreover, in teaching and learning process, assessment is really important to know students' achievement. One of the ways is by administering test to the students.

Weigle (2002) state that writing test involves at least two basic components: one or more writing task or instructions that tell test takers what to write and a means of evaluating the writing samples that test takers produce. English teachers need to assess what they have already inculcated to their students so that they know to what extent the students have achieved the previous formulated instructional objectives. Pedagogically, valid and reliable assessment can give a lot of informative feedbacks to the English teachers, in the sense they are well informed concerning the weakness and the strengths of their teaching. Furthermore, realizing the drawbacks and the strength of their instruction, they can take more effective attempts and measure in dealing with the unsolved problems faced by the students' writing skill.

Based on the interviews which have been carried out at high schools, the English teachers made use of test which were commonly used. They only provided some titles that were related with the materials that have been taught and the students were 
required to write a paragraph based on the title that they have chosen. They were expected to be able to write a paragraph as what has been instructed. The students felt that the tests that were administered by the teachers were not really interesting to do, for this kind of test was familiar for them and they were not motivated to do the tests. To some students, the tests were monotonous so that they were unwilling to do their tests as well as possible. In addition, they found that the tests that were applied were easy for them.

In assessing the students' paragraph writing, the teachers also sometimes did not apply an appropriate scoring which made them feel that their writing was not objectively scored. It also caused the students apathetic and they were unwilling to improve their paragraph writing ability. Therefore, the teachers should try to use more objective scoring rubric which could give more dependable scores towards the students' writing. Besides, they can adapt an available scoring rubric. Budiarta (2017) clearly mentions that the use of scoring rubric can assist them in order to create more objective scoring procedure. There are some available choices of scoring rubric which can be simply adapted for the sake of carrying out an objective scoring process to enhance the students' paragraph writing.

In the present research, the researcher applied writing tests which were categorized as intensive and responsive writing. The tests were respectively guided question and answer, picture description, picture-stimulated writing, dicto-comp, short-story completion task, picturesequence description, picture-cued story sequence task, and picture-cued task. These kinds of tests provided stimuli for the students when they constructed their composition. The stimuli might be in the forms of questions, picture sequence, picture, and recording. The stimuli were provided to help the students in generating their ideas when they wrote the paragraph. The use of stimuli could assist the students when they developed their ideas into much more interesting and eye-catching paragraphs. These kinds of tests were appropriate with the students' writing level.

In addition, the researcher used a scoring rubric to objectively score the students' paragraph writing. In the present study, the researcher applied the scoring rubric which was proposed by (Oshima \& Hogue, 2007). They clearly mention that there are five criteria that should be taken into account in writing a good paragraph. They are format, punctuation and mechanics, content, organization and grammar and sentence structure. These criteria were important since they can be used as guidance to write a paragraph which was interesting for the readers to read. Fulfilling the criteria of writing a paragraph also affected the process of scoring the paragraph; as it was productive, the product should be scored by using scoring rubric which can create more objective scores. An objective scoring was very important as they would feel that their writing was well and carefully checked or scored by their teachers.

In line with the research background which has been previously elaborated, assessing the students' paragraph writing ability was of necessary because writing would be useful in their future lives. Formulating research problems as the focus area in carrying out a research is very important. As what has been aforementioned, the present research was limited on assessing paragraph writing 
ability of high school students through intensive and responsive writing assessment. Furthermore, this research was mainly intended to answer the research problems so that has been previously formulated as follows: how is the achievement of the students' genre paragraph writing ability? and how is the quality of their genre paragraph?

The researcher limited the present study on assessing genre paragraph writing ability of high school students through intensive writing assessment. Accordingly, the present research was strictly focused on assessing genre paragraph writing ability. They were descriptive, recount, and narrative paragraph. In addition, the intensive and responsive writing assessment which were used as follows: guided question and answer, picture description, picture-stimulated writing, dicto-comp, short-story completion task, picture-sequence description, picture-cued story sequence task, and picture-cued task. The genre paragraphs that were written by the students were then scored by using an analytical scoring rubric which emphasized on format, punctuation and mechanic, content, organization, grammar and sentence structure.

\section{METHOD}

\section{Research Design}

The present study, which dealt with assessing text writing ability of high school students through intensive and responsive writing assessment, used an ex post facto research with descriptive analysis. Ex post facto means from what is done afterwards. In the context of social and educational research, the phrase means after the fact or retrospectively and refers to those studies which investigate possible cause and effect relationship by observing an existing condition or state of affairs and searching back in time for plausible causal factors (Cohen et al., 2000, 2007). Besides, Ary et al. (2010) state that the words ex post facto, derived from Latin means "after the fact", indicates that ex post facto research is conducted after the variation in the variable of interest has already been determined in the natural course of events. It shows that the researcher cannot manipulate the independent variable in ex post facto research design.

The main characteristic of this method is that the researcher has no control over the variables; the researcher can only report what has happened or what is happening (Kothari, 2004). Most ex post facto research projects are used for descriptive studies in which the researcher seeks to measure such items as, for example, frequency of shopping, preferences of people, or similar data. According to the explanation above, the present study used an ex post facto research design since the assessment of text writing ability becomes the prior variable that were taken in the present research. In summary, the high school students-since they applied similar curriculum that was 2013 curriculum-have learnt writing through dissimilar quality and quantity of both formal and informal exposures in the target language and they have similar level of text writing ability. In this research, the researcher tried to figure out the achievement of the students and try to descriptively described the quality of their paragraph.

\section{Population and Sample}

Population and sample are essential part in the research study in order to 
develop the focus of study. Tayie (2005) states that one goal of scientific research is to describe the nature of population. Population is group or class of subject, variable, concept, or phenomena. Moreover, Singh (2006) writes that population or universe means the entire mass of observations which is the parent group from which a sample is to be formed. The population may be defined as an aggregate of items possessing a common trait or traits. Sample is a group of part of the population that represents the whole population. Tayie (2005) defines that sample is a part of the population which is taken of the small group that is reachable of being observed in a little amount. In addition, every individual has the equal chance to be taken as the samples of the study.

This study was carried out at the high school students especially in the area of Badung, Gianyar and Denpasar. The high school students in these three regencies were categorized as the population of the present study. In general, the population was regarded to have rather homogenous characteristics in terms some traits, such as socioeconomic background, age, learning motivation, intelligence, aptitude and attitude toward English. Since the population was too big, the researcher then took samples by applying random sampling method in some schools which have already previously determined. Therefore, the samples of the present research were selectively taken from the 16 high schools in the three regencies.

\section{Research Instrument}

As what has been aforementioned, the present ex-post facto research was mainly intended to figure out the achievement of the students' paragraph writing ability which was assessed by administering intensive writing assessment and the quality of the students' paragraph writing ability which was scored by using the scoring rubric adapted from (Oshima \& Hogue, 2007). In order to collect the required data in the present research, the researcher constructed some different research instruments which were developed on the basis of intensive and responsive writing assessment. There were eight different research instruments which were carefully constructed to fulfill the validity and reliability as the necessary characteristics of a good research instruments. The research instruments in the present study were as follows: guided question and answer, picture description, picture-stimulated writing, dicto-comp, short-story completion task, picturesequence description, picture-cued story sequence task, and picture-cued task. These research instruments were administered at 16 different schools in Badung, Gianyar and Denpasar.

\section{DISCUSSION}

\section{The Achievement of the Students' Genre Paragraph Writing Ability}

The present study made use of expost facto research design with descriptive analysis. The findings of the present study were in the form of the converted scores on the basis of norm-reference measure of five standard values that concerned on the achievement of genre paragraph writing ability of high school students in academic year 2016/2017 which had been assessed by administering intensive and responsive writing assessment. The samples were required to write a genre paragraph, 
descriptive, recount or narrative paragraph. The samples had to fulfill five criteria that have been stated in the instructions of the research instrument. Moreover, the genre paragraphs of the samples that were scored by using the scoring rubric were discussed in this section.

Norm-reference measure of five standard values was used to analyze the data which showed excellent, good, sufficient, insufficient and poor achievement of genre paragraph writing. Based on the data analysis which has been previously carried out, it was figured out that there were $5 \%$ of the samples under study who obtained excellent achievement; $27 \%$ of the samples, good achievement; $39 \%$ of the samples, sufficient achievement; $21 \%$ of the samples, insufficient achievement; and $8 \%$ of the samples, poor achievement. Based on the percentages above, the findings of the present study which were collected by administering intensive and responsive writing assessment clearly pointed out the students' success and failure in genre paragraph writing ability.

The abovementioned results clearly showed that the students' achievement on genre paragraph writing was really good. The students' achievement on genre paragraph writing in Gianyar stood out as the highest among the three regencies. In general, based on the aforementioned percentages of norm-reference measure of five standard values, if sufficient achievement was used as the minimum passing grade, there were $71 \%$ of the samples in this study who were categorized as successful and $29 \%$ of the samples were unsuccessful in writing genre paragraphs (i.e., descriptive, recount, and narrative) which were assessed by administering intensive and responsive writing assessment. These results confirmed that the achievement of the students' genre paragraph writing in the present study was good.

In addition, the results of the data analysis obviously pointed out that in writing genre paragraphs, the samples have already shown their well mastery in composing the criteria of a good genre paragraph writing. Among the three genre paragraphs, the students' achievements were mostly on descriptive, recount and narrative paragraph which respectively showed their level of mastery. The samples were really good at writing descriptive paragraph as a lot of samples could show their competency in writing the paragraph. It was quite different with the narrative paragraph which required students work harder so that their paragraph might achieve much better results. The samples found it easier to write a descriptive paragraph because they could manage their paragraph by using the simple present tense which was the basic tense.

\section{The Quality of the Students' Genre Paragraph}

Based on the results of the data analysis, it was clearly shown that the students could write a descriptive paragraph better than the other two genre paragraphs, recount and narrative paragraph. The researcher was then really interested to figure out the quality of their genre paragraphs. As what has been aforementioned, to analyze the quality of the genre paragraphs which were written by the students, the researcher made used of an analytical scoring rubric which was adapted from (Oshima \& Hogue, 2007). The researcher used the scoring rubric which 
had five criteria such as format, punctuation and mechanics, content, organization, and grammar and sentence structure. The elaboration of each criterion in the scoring rubric can be read as follows.

The result of the present research showed that in terms of format of the genre paragraph, most of the samples under study were good in writing the genres paragraph by using the correct format. All of the three genre paragraphs were written by providing and placing the title in the center. All of the samples' genre paragraphs had a title and most of the samples could write a paragraph with appropriate title. In writing the genre paragraphs, they have already fulfilled another requirement of format such as the first sentence of the paragraph should be indented. They also put margins on both sides of the genre paragraph so that it looked well-developed. Thus, most of the samples' genre paragraphs got the maximum point on those criteria. However, most of the samples under study still did not pay attention on the tidiness of the paragraph. It might happen because they had limited time to finish their paragraphs.

Based on the assessment of punctuation and mechanics, most of the samples' genre paragraphs were good enough. They have already ended every sentence in the paragraph with a period. They put the period to end their sentences so that their texts could be well and easily understood. Moreover, the samples of the present study were also able to write the genre paragraphs with correct spelling and also put commas and other punctuation correctly. Thus, it made their paragraphs were readable and easy to be understood. Based on these results, the researcher could find that the samples under the study were good in spelling and they understood about using a correct punctuation. However, some samples were not able to use capital letters correctly. They often forgot to use them after the period, the name of region, and the name of the street. Moreover, a few of them capitalized the letters in the center of the sentence.

Furthermore, most of the content of the genre paragraph was good. Most of the samples under study did not have problem in the content. Most of the samples were able to write based on the instructions that were given. They could compose a wellstructured genre paragraph which was unified and coherent. They had a good capability in making a unified genre paragraph. Their sentences talked about one idea and each sentence was related to the topic. The samples could develop their ideas in a good way and also used their imagination. Most of the samples wrote the genre paragraphs based on the instructions which have been provided. However, some of them still had difficulties to fit the assignment. They were unable to write sentences in the paragraph that were based on the required number of the sentences in the genre paragraphs. A few students were less than the required number and the other more than the required number of sentences that were instructed in the research instruments.

In terms of organization in writing the genre paragraphs, the samples under study generally were able to organize the paragraph quite well with the generic structure of descriptive, recount and narrative paragraph. Based on the samples' genre paragraphs, most of them were able to start writing their genre paragraph with suitable opening such as identification and an orientation in both recount and narrative paragraph. In the description about the 
object being described, they were able to describe the object clearly with detail descriptions such as the look of the object so that the readers could easily visualize it. In recount paragraph, they were also able to write good events which were logically arranged based on the order of time. Finally, they could end the paragraphs by writing the conclusion in descriptive paragraph and reorientation in recount and narrative paragraph. However, the researcher found that there were some of the samples who still struggled in writing a good complication in narrative paragraph which step-by-step arouse that created tension. This made their narrative paragraph become uninteresting and monotonous to read.

Based on the genre paragraphs which were written by the students, the samples have organized the genre paragraphs well in terms of grammar and sentence structure. They could write a good descriptive paragraph which made use of simple present tense. In term of grammar and sentence structure, some of the students could use the present tense in describing about person, place, or thing. Most of the samples wrote the descriptive paragraph in grammatically correct and also made a good sentence structure on their paragraphs. They recognized the usage of present tense in the descriptive paragraphs. Their descriptive paragraph was much better than the other two genre paragraphs, recount and narrative paragraph. On the other hand, grammar and sentence structure still became fundamental problem some of the samples especially when they wrote recount or narrative paragraphs. Even they had already learnt about past tenses which were dominantly used in recount and narrative paragraph, they still used the tenses incorrectly. Some students were quite confused in using regular and irregular past tense. Moreover, they still translated Bahasa Indonesia into English so that their texts were ungrammatical.

\section{CONCLUSION}

The present research entitled "Assessing Genre Paragraph Writing Ability of High School Students through Intensive and Responsive Writing Assessment" made use of an ex-post facto research design with descriptive analysis. The result of the data showed that there were $71 \%$ of the samples who were successful in writing genre paragraphs. However, 29\% samples were unsuccessful in writing the genre paragraphs. It meant that there were some samples understudy who could write the genre paragraphs well and a few samples still found difficulties in writing the genre paragraphs. In addition, in terms of the quality of their genre paragraph, they could write a good quality descriptive paragraph that fulfilled format, punctuation and mechanics, content, organization, and grammar and sentence structure. The researcher could take a note that it should be careful in generalizing the findings to the whole population. Furthermore, this was due to the fact that research findings had rather limited validity and reliability.

\section{REFERENCES}

Ary, D., Jacobs, L. C., \& Sorensen, C. (2010). Introduction to research in education (8th ed.). Belmont: Wadsworth Cengage Learning.

Brown, H. D. (2004). Language Assessment: Principles and Classroom Practices. White Plains, NY: Pearson Education, Inc.

Budiarta, I. K. (2017). Applying 
Simultaneous Roundtable to Improve Genre-based Paragraph Writing Ability. Jurnal Santiaji Pendidikan, 7(2), 150-161.

Cohen, L., Manion, L., \& Morrison, K. (2000). Research methods in education (5th ed.). London: RoutledgeFalmer.

Cohen, L., Manion, L., \& Morrison, K. (2007). Research methods in education (6th ed.). New York: Taylor \& Francis Group.

Kothari, C. R. (2004). Research methodology: Methods and techniques (2nd ed.). New Delhi: New Age International (P) Ltd., Publishers.

Oshima, A., \& Hogue, A. (2007). Introduction to academic writing (3rd ed.). White Plains, NY: Pearson Education, Inc.

Singh, Y. K. (2006). Fundamental of research methodology and statistics. New Delhi: New Age International (P) Ltd., Publishers.

Tayie, S. (2005). Research methods and proposals research methods and writing research proposals. Cairo:

Center for Advancement of Postgraduate Studies and Research in Engineering Sciences, Faculty of Engineering - Cairo University (CAPSCU).

Weigle, S. C. (2002). Introduction. In J. C. Alderson \& L. F. Bachman (Eds.), Assessing Writing. Cambridge: Cambridge University Press. 